\title{
Microbiological and Clinical Aspects of Tularemia Disease
}

\section{Oto Pavlis ${ }^{1,2 *}$, Zlatko Janeba ${ }^{3}$, Zuzana Cermakova ${ }^{4}$ and Miroslav Pohanka ${ }^{2}$}

${ }^{1}$ Central Military Health Institute, Centre of Biological Defence, Techonin, Czech Republic

${ }^{2}$ Faculty of Military Health Service, University of Defence, Tebesska, Hradec Kralove, Czech Republic

${ }^{3}$ Institute of Organic Chemistry and Biochemistry, Flemingovo nam. Prague, Czech Republic

${ }^{4}$ Department of Clinical Microbiology, Charles University in Prague, Faculty of Medicine in Hradec Kralove and University Hospital in Hradec Kralove, Czech Republic

\section{Summary}

Francisella tularensis ranks among the most significant biological agents exploitable for bioterrorism and biological warfare. The reasons why $F$. tularensis is considered to be a militarily exploitable organism with high relevance for human as well as veterinary medicine are high virulence, quick spreading through vectors and stability in the aerosol combined with good pulmonary transmission. The aim of the text is to summarise in a transparent way current knowledge of tularemia and outline the destiny of the generator of the disease in the organism. Attention is paid to immunological aspects of the disease, ways of treatment and diagnostic processes.

Keywords: Francisella tularensis; Tularemia; Immune system; Scavenger cells; TLR receptors; Antibodies; Antibiotics; PCR

\section{Introduction}

Francisella tularensis (F. tularensis) is a facultative intracellular gram-negative bacterium. Morphologically it is an aerobic, non-motile coccobacillus which does not have the capability of creating spores and whose dimension does not exceed $0.8 \mu \mathrm{m}$. F. tularensis is the generator of the zoonotic disease of tularemia. The discovery of the generator of the disease dates to the beginning of the twentieth century when a strange plague of rodents spread in the area of Tulare in California. The generator was described in the year 1911 [1] and isolated a year later [2]. At present, the population of hares, rodents and other small mammals in wide open space is considered as the significant reservoir of tularemia. Among significant natural reservoirs, e.g. muskrats (Ondatra zibethicus), beavers (Castor canadensis), water-rats (Arvicola terrestris), hares (Lepus spp) and field mice (Microtus arvalis) can be rated [3]. The vectors are mainly ticks, but mosquitos have also been speculated on $[4,5]$.

\section{A culture of Francisella tularensis LVS on McLeod's chocolate agar}

F. tularensis ranks among the most significant biological agents exploitable for bioterrorism and biological warfare [6]. The reasons why F. tularensis is considered as militarily exploitable organism are high virulence, quick spreading through vectors and stability in the aerosol combined with good transmission by respiratory way [7] (Figure 1).

The aim of this text is to summarise in a transparent way current knowledge of tularemia and outline the life cycle of the generator of the disease in the organism. Attention is paid to immunological aspects of the disease, ways of treatment and diagnostic processes.

The prevalence of affection by tularemia in people in the Czech Republic was of $0.5 \%$ in the year 2010, a year earlier, $0.62 \%$ for 100000 inhabitants (SZÚ, EPIDAT). The most represented reservoir animal are mice, hamsters and hares (primarily Russia), from vectors consequently mosquitos (Sweden, Finland, Russia) and ticks (Central Europe) [8]. It results from the study carried out in the Republic of Kosovo that was done in the period of May - July the presence of $F$. tularensis in ticks was of $65 \%$, the presence at reservoir animals, above all at hares, was in the period of November - December of $33 \%$, in the period of May - July of $22 \%$ [9].

\section{F. tularensis as generator of tularemia}

We distinguish in total four subspecies: F. tularensis subspecies (subsp.) tularensis (or also F. tularensis type A), holarctica (F. tularensis type B), novicida and mediaasiatica. F. tularensis occurs in the United States, Canada, countries of Europe, Asia and in Japan. The most virulent tribes, belonging to the tularensis subtype, range in the territory of North America. In Europe and Asia, there occurs predominantly the holarctica subtype, which is found also in the territory of the Czech Republic. F. tularensis is the generator of tularemia. The transmission to man can occur in various ways, according to which we distinguish in total four forms of disease: ulceroglandular, oculoglandular, typhoid and pulmonary. For the ulceroglandular form of disease, the ulcerative lesion in the place of penetration through skin and enlargement of declining lymphatic nodules is characteristic. In the oculoglandular form, the infection penetrates through conjunctiva, it manifests by blenophthalmia. The typhoid form is accompanied by haemorrhage and ulcerous alterations in the alimentary tract, it happens by ingestion of contaminated food or water. The most serious is the pulmonary form which originates either by direct inhalation of contaminated

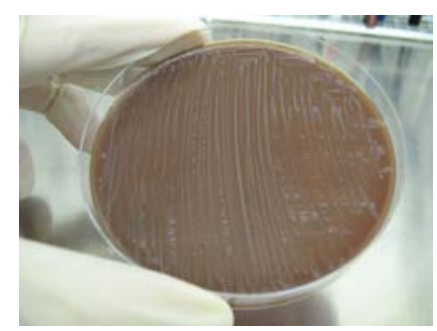

Figure 1: A culture of Francisella tularensis LVS on McLeod's chocolate agar.

*Corresponding author: Oto Pavlis, Central Military Health Institute, Centre of Biological Defence, 56166 Techonin, Czech Republic, Tel: 420973273509; E-mail: oto.pavlis@email.cz

Received April 16, 2012; Published July 26, 2012

Citation: Pavlis O, Janeba Z, Cermakova Z, Pohanka M (2012) Microbiological and Clinical Aspects of Tularemia Disease. 1: 168. doi: ${ }^{\text {TM } 10.4172 / \text { scientificrep- }^{2}}$ orts. 168

Copyright: (C 2012 Pavlis O, et al. This is an open-access article distributed under the terms of the Creative Commons Attribution License, which permits unrestricted use, distribution, and reproduction in any medium, provided the original author and source are credited. 
aerosol or as a result of haematogenous dissemination of bacteria from distal body parts. It manifests as a systemic disease with these manifestations: pharyngitis, trachitis or bronchitis, pulmonitis, pleuritis and incrassation of nodules, which can lead up to pneumonia with respiratory failure and consequent death.

The disease manifests clinically after 3 to 7 days of incubation. Patients suffer from the feeling of a chill or shivering fit, temperature rises to $38-39^{\circ} \mathrm{C}$ or even higher. Vehement pains of head, muscles and joints, vertigo, general asthenia, loss of appetite, insomnia and night sweats are described.

Diseases are caused in people by F. tularensis subsp. tularensis and subsp. holarctica, whereas F. tularensis subsp. holarctica is responsible for less serious cases of tularemia. The LVS (Live Vaccine Strain) vaccine tribe - still used for the study of tularemia, was deduced just from this subtype. The novicida and mediaasiatica subtypes are nonpathogenic for human beings [10].

\section{Pathogen invasion}

In the organism, F. tularensis is found in scavenger cells, dendritic cells, hepatocytes, alveolar epicytes and extra-cellular then in the blood of infected animals. The virulence of this bacterium is connected with its ability of replication inside host cells. It escapes quickly from phagosome and replicates in cytosol of host cells. After replication (c. 24 hours after infection) it enters the endosome part of a cell [11].

F. tularensis is growth-demanding, it requires the presence of iron and compounds containing - $\mathrm{SH}$ group (for instance, cysteine which is an important growth factor for it). A study with ggt mutant of $F$. tularensis, which is not able to split gamma-glutamyl of cysteine bond and obtain thus cysteine by splitting of glutathione, was made. The in vivo experience with this mutant on mice $\mathrm{BALB} / \mathrm{c}$ demonstrated a difference in medium fatal dose by the LVS tribe $\left(10^{1}\right)$ and ggt mutant $\left(10^{4.8}\right)$ [12].

The bacterium is, upon entering the scavenger cell, surrounded by long, non-symmetric loops of pseudopodia and ignominiously pulled in the cell. This way of ingestion is different against other bacteria which enter the cells by standard phagocytosis during which pseudopodia of cytoplasm are smaller and symmetric. An accurate, by a receptor mediated mechanism of entering into the cell is not known, but we suppose involvement of complement receptors, $\mathrm{Fc}$ - receptors, a mannose receptor and TLR (Toll-Like Receptor) receptors, specifically TLR2. We can result from the knowledge of capability of scavenger cells to recognize structures at the surface of microorganisms. There are concerned groups of molecules whose structure is typical for individual microorganisms, e.g. endotoxins of gram-negative bacteria, peptidoglycans, glucans, phospholipides, etc., which we include under the name of PAMP structure (Pathogen Associated Molecular Patterns). These molecules are recognized by the so-called PRR (pathogen recognition receptors) which are expressed predominantly at cells presenting antigen (scavenger cells and dendritic cells). The main task of these receptors is opsonization, phagocytosis, activation of complement and pro-inflammatory signal ways and induction of apoptosis. As has already been noted, the mannose receptor, scavenger receptor, complement receptor, $\mathrm{Fc}$ - receptor and the TLR group (Toll - Like Receptors) of receptors ensure the phagocytosis of microorganisms on the surface of scavenger cells. The name TLR is derived from the receptor described at fruit fly (Drosophila). At present, thirteen TLRs are known [13].

\section{Activation of immune system}

After activation of different types of TLR, there occurs the initiation of a signalling cascade whose character depends on the quantity of lipopolysaccharide (LPS) antigen and three-dimensional shape of its end point, constituted by lipid A [14].

TLR receptors are consequently primarily expressed on cells presenting antigen. The recognition of microbial products by these receptors leads to the activation of nuclear factor kappa B (NF- $\kappa \mathrm{B}$ ), mitogen-activated protein kinase and to induction of co-stimulating molecules. The ability of TLR receptors to influence the production of immune-regulation cytokines and modulation of expression of costimulating molecules reflects their decisive role at protal as well as adaptive part of immune system which we can illustrate in the example of TLR-2 receptor. By means of this receptor, F. tularensis stimulates the production of pro-inflammatory cytokine TNF- $\alpha$ and increased regulation of expression MHC class II, CD80, CD86 and CD40 [15].

TLR receptors are not, however, only a domain of cells presenting antigen but also of mature B cell expressing these receptors (TLR- 4 and TLR-2) on its surface. During recognition of microbial products, there occurs activation of other cells, above all of scavenger cells, by means of cytokines IL-6, TNF- $\alpha$ and $\beta$ and IL-12. B cells can be activated by signalization through TLR-4-MyD88 path. This way of B cell activation was monitored with the help of the effect of thermal shock protein of the size of $60 \mathrm{kDa}$ (HSP60) in mice which have never been presented to any pathogen so far. The soluble HSP 60 induced proliferation of B cells and secretion of IL-10 and IL-6. B cells also regulated increasingly the expression of MHC II and several significant surface markers (CD69, CD40 and B7-2) [16].

Another way of B cell activation is by the stimulation of lipopolysaccharide (LPS), which leads to proliferation and secretion of IgM. B cells have two TLR receptors which can mediate LPS signalization, TLR-4 and RP105 (CD180). RP105 is a trans-membrane protein of type I of the size of $105 \mathrm{kDa}$. Its protective function, protecting B cells against apoptosis induced by irradiation, is stated. RP105 is expressed predominantly on mature B cells at mice and on human dendritic and B cells [17].

\section{Antibiotics treatment}

In previous years, aminoglycoside antibiotics were used for the treatment of tularemia, above all streptomycin; dose of 7.5-10 mg/ $\mathrm{kg}$ every 12 hours $i . m$. for the duration of 7-14 days. Streptomycin is presently used for its serious adverse effects, such as ototoxicity, only in isolated cases (e.g. at tularemic meningitis). It was substituted by another aminoglycoside antibiotic - gentamicin, which is administered in a dose of $3-5 \mathrm{mg} / \mathrm{kg} /$ day in intravenous infusion also for the period of 7-14 days. It is recommended to administer simultaneously doxycycline of 100-200 mg once a day p. o. [18].

A study by Scandinavian microbiologists proves that another potential alternative for the treatment of tularemic infection are quinolone antibiotics, e.g. ciprofloxacin, levofloxacin, grepafloxacin and trovafloxacin. A Minimum Inhibitive Concentration (MIC) of representatives of several classes of Antibiotics (ATB) in 38 isolates, from that 20 of human origin and 18 of animal origin (16 samples from a hare and 2 samples from a muskrat) was set. In the experiment, collection tribes ATCC 6223 F. tularensis subsp. tularensis and ATCC 29864 F. tularensis (biovar F. tularensis palaearctica) were used as a control. Quinolone ATB demonstrated $\mathrm{MIC}_{90}$ smaller than $0.05 \mathrm{mg} / \mathrm{L}$; 
in comparison with streptomycin $(4 \mathrm{mg} / \mathrm{L})$ and gentamicin $(1 \mathrm{mg} / \mathrm{L})$ [19].

\section{Diagnosis of tularemia}

Tularemia can be simply diagnosed by assessment of specific antibodies level in serum or plasma. The increased level of antibodies can be diagnosed even a few days after infection as evidenced for $\mathrm{BALB} / \mathrm{c}$ mice infected with $F$. tularensis LVS in an experiment [20]. Though the immunodiagnosis is quite sensitive, it can suffer from low specificity as cross reactivity between antibodies against $F$. tularensis and Brucella sp. may be expected. For this reason, brucellosis cannot be revealed properly until tularemia is not excluded [21]. The cross reactivity of antibodies can be reduced by addition of dithiothreitol into the examined sample [22].

In the body, bacterial burden culminates approximately five days after disease beginning and it vanishes after approximately 20 days [23]. The presence of bacterium in host can be revealed by Polymerase Chain Reaction (PCR) with good sensitivity and selectivity. Proves of tul4 and fopA genes coding 17 and $43 \mathrm{kDa}$ proteins of $F$. tularensis outer membrane are suitable for tularemia diagnosis [24,25]. Amplification of genes for chaperones cpn10, cpn60 and 16S rRNA is known and recommended by some investigators for a reliable diagnosis of tularemia [26,27]. Biopsies of lymph nodes and plasma are samples well suitable for the assays purposes.

The genetic investigation is reliable for reveal of running tularemia. On the other hand, resolving of the disease leads typically to negative prove of the disease by genetic tests. In an example, twenty-year old woman was infected with tularemia five months prior to laboratory examination [28]. Specific antibodies as well as $\mathrm{C}$ reactive protein were significantly elevated; however, genetic tests based on PCR were negative. Considering actual methods for tularemia diagnosis, PCR (mainly in real time variant), microagglutination, immunofluorescence and enzyme linked immuno-sorbent assay can be mentioned as the main tools for a reliable reveal of tularemia [29].

Necessity to diagnose tularemia is conditioned by epidemiologic situation. Presence of tularemia in wild animals as a natural reservoir fluctuates in course of weather conditions and social aspects [30]. Tularemia is a zoonotic disease and humans can be simply infected from animals. The most probable is contact with animals in lower altitude especially in alluvial regions [31]. Gradation of rodents populations are a risk factor for tularemia outbreak [32-34] therefore the laboratory diagnosis should be done for patients with an infectious disease coming into contact with wild animals.

\section{Conclusion}

Tularemia is a dangerous infectious zoonotic disease which can be brought in the population from animal reservoirs. In spite of a low contamination of the European population, tularemia cannot be considered as well manageable infectious disease. On the contrary, its treatment and diagnostics are relatively demanding and are connected to specifics related to the pathogenesis of microorganisms. This text summarizes in a transparent form the necessary data for understanding pathological processes of tularemia, its diagnostics and pharmacological treatment and submits them to the reader compact with references to specialized works dedicated to real aspects.

\section{Acknowledgements}

The article originated as part of the project which is financially supported by the Ministry of the Interior of the Czech Republic (VG20102015046).
One of the goals of this project is the testing of the antibiotic properties of newly synthesized substances on a series of selected microorganisms, specifically on Bordetella pertussis, Bacillus anthracis, Yersinia pestis, Escherichia coli, Bacillus subtilis, Listeria monocytogenes, Salmonella enteritidis, Pseudomonas aeruginosa, Acinetobacter baumannii, Mycobacterium tuberculosis, and Staphylococcus aureus and on the above mentioned Francisella tularensis.

\section{References}

1. McCoy GW (1911) Studies upon plague in ground squirrels. A plague-like disease of rodents. Public health bulletin Washington, DC 43

2. McCoy GW, Chapin CW (1912) Further observation on a plague-like disease of rodents with a preliminary note on the causative agent: Bacterium tularense. The Journal of Infectious Diseases 10: 61-72.

3. Morner T (1992) The ecology of tularemia. Rev Sci Tech 11: 1123-1130.

4. Reese SM, Petersen JM, Sheldon SW, Dolan MC, Dietrich G, et al. (2011) Transmission efficiency of Francisella tularensis by adult american dog ticks (Acari: Ixodidae). J Med Entomol 48: 884-890.

5. Gyuranecz M, Rigó K, Dán A, Földvári G, Makrai L, et al. (2011) Investigation of the ecology of Francisella tularensis during an inter-epizootic period. Vector Borne Zoonotic Dis 11: 1031-1035.

6. Gallagher-Smith M, Kim J, Al-Bawardy R, Josko D (2004) Francisella tularensis possible agent in bioterrorism. Clin Lab Sci 17: 35-39.

7. Foley JE, Nieto NC (2010) Tularemia. Vet Microbiol 27: 332-338.

8. Vorou RM, Papavassiliou VG, Tsiodras S (2007) Emerging zoonoses and vector-borne infections affecting humans in Europe. Epidemiol Infect 135 1231-1247.

9. Reintjes R, Dedushaj I, Gjini A, Jorgensen TR, Cotter B, et al. (2002) Tularemia outbreak investigation in Kosovo: case control and environmental studies. Emerg Infect Dis 8: 69-73.

10. Dennis DT, Inglesby TV, Henderson DA, Bartlett JG, Ascher MS, et al. (2001) Tularemia as a biological weapon: medical and public health management. JAMA 285: 2763-2773.

11. Cole LE, Santiago A, Barry E, Kang TJ, Shirey KA, et al. (2008) Macrophage proinflammatory response to Francisella tularensis live vaccine strain requires coordination of multiple signaling pathways. J Immunol 180: 6885-6891.

12. Alkhuder K, Meibom KL, Dubail I, Dupuis M, Charbit A (2009) Glutathione provides a source of cysteine essential for intracellular multiplication of Francisella tularensis. PLoS Pathog 5: e1000284.

13. Carpenter S, O'Neill LA (2007) How important are Toll-like receptors for antimicrobial responses? Cell Microbiol 9: 1891-1901.

14. Luft C, Hausding M, Finotto S (2004) Regulation of T lymphocytes in asthma: implications for gene manipulation. Curr Opin Allergy Clin Immunol 1: 60-64.

15. Katz J, Zhang P, Martin M, Vogel SN, Michalek SM (2006) Toll-like receptor 2 is required for inflammatory responses to Francisella tularensis LVS.Infect Immun 74: 2809-2816.

16. Cohen-Sfady M, Nussbaum G, Pevsner-Fischer M, Mor F, Carmi $P$, et al. (2005) Heat shock protein 60 activates B cells via the TLR4-MyD88 pathway. J Immunol 175: 3594-3602.

17. Yazawa N, Fujimoto M, Sato S, Miyake K, Asano N, et al. (2003) CD19 regulates innate immunity by the toll-like receptor RP105 signaling in B lymphocytes. Blood 102: 1374-1380.

18. Dlugaczyk J, Harrer T, Zwerina J, Traxdorf M, Scharz S, et al. (2010) Oropharyngeal tularemia--a differential diagnosis of tonsillopharyngitis and cervical lymphadenitis. Wien Klin Wochenschr 122: 110-114.

19. Ikäheimo I, Syrjälä H, Karhukorpi J, Schildt R, Koskela M (2000) In vitro antibiotic susceptibility of Francisella tularensis isolated from humans and animals. J Antimicrob Chemother 46: 287-290.

20. Pohanka M, Pavlis O, Skládal P (2007) Diagnosis of tularemia using piezoelectric biosensor technology. Talanta 71: 981-985

21. Russell AO, Patton CM, Kaufmann A (1978) Evaluation of the card test for diagnosis of human brucellosis. J Clin Microbiol 7: 454-58.

22. Behan KA, Klein GC (1982) Reduction of Brucella species and Francisella tularensis cross-reacting agglutinins by dithiothreitol. J Clin Microbiol 16: 756757. 
Citation: Pavlis O, Janeba Z, Cermakova Z, Pohanka M (2012) Microbiological and Clinical Aspects of Tularemia Disease. 1: 168. doi: ${ }^{\mathrm{TM}} 10.4172 /$ scientificreports. 168

23. Ray HJ, Cong Y, Murthy AK, Selby DM, Klose KE, et al. (2009) Oral live vaccine strain-induced protective immunity against pulmonary Francisella tularensis challenge is mediated by CD4+ $\mathrm{T}$ cells and antibodies, including immunoglobulin A. Clin Vaccine Immunol 16: 444-452.

24. Ellis J, Oyston PC, Green M, Titball RW (2002) Tularemia. Clin Microbiol Rev 15: $631-646$

25. Hepburn MJ, Simpson AJ (2008) Tularemia: current diagnosis and treatment options. Expert Rev Anti Infect Ther 6:231-240.

26. Ericsson M, Golovliov I, Sandström G, Tärnvik A, Sjöstedt A (1997) Characterization of the nucleotide sequence of the groE operon encoding heat shock proteins chaperone- 60 and -10 of Francisella tularensis and determination of the T-cell response to the proteins in individuals vaccinated with F. tularensis. Infect Immun 65: 1824-1829.

27. Maurin M, Castan B, Roch N, Gestin B, Pelloux I, et al. (2010) Real-time PCR for diagnosis of oculoglandular tularemia. Emerg Infect Dis 16: 152-153.

28. Lübbert C, Taege C, Seufferlein T, Grunow R (2009) [Prolonged course of tick-borne ulceroglandular tularemia in a 20 -year-old patient in Germany--case report and review of the literature]. Dtsch Med Wochenschr 134: 1405-1410.

29. Maurin M, Pelloux I, Brion JP, Del Banõ JN, Picard A (2011) Human tularemia in France, 2006-2010. Clin Infect Dis 53: e133-141.

30. Hubálek Z (2005) North Atlantic weather oscillation and human infectious diseases in the Czech Republic, 1951-2003. Eur J Epidemiol 20: 263-270.

31. Pikula J, Treml F, Beklová M, Holesovska Z, Pikulová J (2003) Ecological conditions of natural foci of tularaemia in the Czech Republic. Eur J Epidemiol 18: 1091-1095.

32. Cerný Z (2002) [Tularemia--history, epidemiology, clinical aspects, diagnosis and therapy]. Cas Lek Cesk 141: 270-275.

33. Gurycová D, Výrosteková V, Khanakah G, Kocianová E, Stanek G (2001) Importance of surveillance of tularemia natural foci in the known endemic area of Central Europe, 1991-1997. Wien Klin Wochenschr 113: 433-438.

34. Cerny Z (2000) [Tularemia--an old and a new problem in the South Moravia Region]. Bratisl Lek Listy 101: 402-408. 